\title{
Maximilano A. Soler Bistué (ed.), Libro de loS fueros de Castilla, Buenos Aires, SECRIT, 2016, 320 PÁGS. ISBN: 978-987-25253-4-7.
}

\author{
Manuel Hijano Villegas \\ University of Durham
}

Maximiliano Soler Bistué nos ofrece una cuidada edición crítica de los textos recogidos en el manuscrito 431 de la Biblioteca Nacional de España, códice de la segunda mitad del siglo XIV bien conocido por los historiadores del Derecho por ser testimonio único de varias obras fundamentales del derecho señorial castellano. La redacción de las tres primeras obras data del siglo XIII: el Libro de los fueros de Castilla, una colección de fueros y fazañas que supone el primer intento conocido por poner por escrito el derecho señorial en su conjunto; las Devisas que an los señores en sus vasallos, un conjunto de disposiciones reunidas por un jurista privado relativas a las prestaciones señoriales en las behetrías, y el Pseudo-Ordenamiento de Nájera II (PONII), texto antecesor del Fuero Viejo de Castilla de 1356. A estos tres textos del siglo XIII el compilador del siglo XIV añadió otros tres, alguno de ellos de índole no estrictamente jurídica: una copia del primer testamento de Alfonso X otorgado en Sevilla en 1283; la célebre Leyenda de la blasfemia del Rey Sabio, recogida, en una versión distinta, por la Crónica de 1344, y por último, una Colección de fazañas de época de Pedro I, cuya puesta por escrito pudo ser obra del responsable de la colección. La edición va precedida de un extenso estudio introductorio dividido en cuatro capítulos, en los que Soler Bistué, expone los criterios histórico-filológicos que han guiado la labor editorial, sitúa el manuscrito y sus contenidos dentro de su contexto socio-político y plantea un novedoso acercamiento a los textos, más allá de su valor testimonial como fuente del derecho territorial castellano, como productos ideológicos partícipes de las pugnas por el poder entre monarquía y nobleza libradas en Castilla durante el periodo que abarca desde el final del reinado de Alfonso $\mathrm{X}$ hasta la ascensión al trono de la dinastía Trástamara.

Entre las muchas cualidades de la edición destaca la de brindarnos la totalidad del contenido del manuscrito, una decisión que se hace eco del protagonismo que el medievalismo actual otorga al manuscrito en reconocimiento del valor hermenéutico que encierran todos sus componentes, tanto lingüísticos como materiales. En el caso del manuscrito 431, el respeto a la integridad del manuscrito resulta especialmente acertado, por cuanto la recopilación del siglo XIV parece haber obedecido a una intencionalidad deliberada y resulta obligada, por tanto, una lectura conjunta de los textos, como partes funcionales de un todo, a fin de establecer su tipología y la funcionalidad ideológica 
que tuvieron dentro de su contexto de producción y recepción. Algunas de las claves para dicha lectura conjunta nos las ofrece Soler Bistué en la introducción.

El capítulo 1 expone una argumentada hipótesis sobre el origen y la transmisión del llamado "derecho señorial castellano", cuyas implicaciones son desarrolladas en el resto de la introducción e informan la totalidad del proyecto editorial. Con buen criterio, se evitan las referencias a los episodios, entre la historia y la leyenda, asociados a los orígenes del derecho señorial (el rechazo castellano al Fuero Juzgo leonés, la elección de los jueces, los fueros y libertades otorgados por el conde Sancho García y su reconocimiento en las cortes de Nájera), para centrarse en la puesta por escrito del corpus en los siglos XIII y XIV. Para el investigador la codificación de fueros, fazañas y sentencias del derecho consetudinario no obedeció, en primera instancia, a consideraciones prácticas (esto es, la producción de textos que facilitasen la labor de jueces y abogados implicados en los procesos judiciales), sino que debe interpretarse como un acto político, en virtud del cual la alta nobleza castellana expresó su rechazo a las iniciativas legislativas emprendidas por la monarquía en dos momentos históricos concretos: los reinados de Alfonso X y Alfonso XI. El manuscrito 431 constituye, por tanto, un "acontecimiento discursivo" (pág. XCVI), en la expresión foucauldiana empleada por Soler Bistué, en la medida que en él conviven superpuestas estas dos fases de la enunciación del discurso jurídico nobiliario: en la primera, manifestada en el terreno político por la rebelión de Lerma de 1271 y la guerra civil de 1282-84, se situaría la redacción del Libro de los fueros de Castilla, las Devisas y el Pseudo-Ordenamiento de Nájera II, así como la creación de la Leyenda de la blasfemia de Alfonso X, probablemente en la corte de Sancho IV y en respuesta al polémico contenido del testamento paterno; en la segunda fase se inscribirían, por su parte, la redacción sistemática del Fuero Viejo de Castilla en 1356 y la formación del manuscrito 431, obras de las que se vale la nobleza para reafirmar sus derechos y privilegios amenazados por la promulgación del Ordenamiento de Alcalá por Alfonso XI en 1348. El capítulo prosigue pasando revista a diversos planteamientos críticos sobre la historia del derecho señorial, deteniéndose especialmente en valorar las propuestas de José Manuel Pérez-Prendes y Muñoz de Arraco, para quien los textos representan una "señoralización" del derecho, es decir, una apropiación del discurso jurídico por parte de la élite nobiliaria, movida por la voluntad no tanto de intervenir en todos los aspectos de la vida social, como por la de exhibir y dejar constancia escrita de su capacidad histórica de ejercer funciones jurídicas. Desde esta premisa, Soler Bistué señala que resulta baldío sostener, como hace Javier Alvarado Planas (2004), el origen regio de la legislación en base a una supuesta autenticidad de las menciones que algunos de los textos hacen a la monarquía como instancia otorgadora o refrendadora de las leyes, pues la cuestión en juego a la hora de establecer la dimensión ideológica del derecho señorial no es la fuente ni los contenidos de la norma jurídica, sino quién (y en servicio de qué intereses) la asume y proclama como propia.

El capítulo 2 proporciona los datos que tradicionalmente cabe esperar en la introducción de una edición crítica: una meticulosa descripción del códice, un comentario de sus contenidos y una propuesta de autoría. En cuanto al último apartado Soler Bistué sitúa la 
labor de compilación y rescritura de la colección en "algún centro de producción ajeno a la corte regia de Pedro I, un scriptorium ligado a alguna de las grandes familias de la aristocracia castellana" (pág. LXXXII), una atribución que el lector pudiera encontrar excesivamente tímida, por cuanto el investigador aporta argumentos de suficiente peso, tanto en el capítulo precedente como en el posterior análisis del Testamento y la Leyenda de la blasfemia de Alfonso X, sobre el carácter anti-petrista de la obra como para permitir vincular la compilación, e incluso la producción del códice, a algún partidario de los Trastámara, si no al propio entorno de Enrique II.

El capítulo 3 propone una lectura de los textos atendiendo a su ordenamiento secuencial, que pone de relieve la disposición estratégica de los textos de índole más claramente antimonárquica (Testamento de Alfonso X y Leyenda de la blasfemia) y la manera en que iluminan el carácter ideológico de las tres obras del siglo XIII y de la totalidad de la colección. Este enfoque sintagmático viene complementado, en el Capítulo 4, por un estudio de la fazaña, a la que se identifica como el paradigma formal y temático al que se atienen los textos recogidos en el manuscrito. El análisis narratológico de varias de estas fazañas revela que nos encontramos ante un discurso que despliega las estrategias propias de la ficción narrativa para implicar al receptor en un universo socio-jurídico ejemplar, el del pasado castellano anterior a la intromisión legislativa de los reyes, acorde con una lógica fundada en la excepcionalidad de la clase de los caballeros fijosdalgos y el principio de "desigualdad ante la ley" (pág. CXXIII), en la afortunada expresión del autor. En la creación de este universo ficticio tan importante es lo que el discurso revela como lo que oculta y, en este sentido, Soler-Bistué señala algunos silencios significativos del texto, especialmente su omisión de referencias a las facultades legislativas del monarca o a la obra legislativa de Alfonso X en la historia del derecho castellano que abre la Colección de fazañas del siglo XIV, una ausencia similar a la que José Manuel Pérez-Prendes y Muñoz de Arraco observaba en el prólogo del Fuero Viejo de Castilla (págs. CXVII-CXVIII y CXXVIII-CXXIX).

El texto crítico en sí hace patente la sólida formación filológica del editor y su experto conocimiento de la teoría y la práctica de la crítica textual. Dado que se trata del único testimonio de la mayoría de los textos, las intervenciones editoriales se suelen circunscribir a enmendar aquellos elementos del manuscrito que razonablemente pueden ser atribuidos a errores en el proceso de copia, destinando las notas a pie de página a consignar las intervenciones del editor y a discutir las soluciones propuestas en anteriores ediciones. Me parecen irrefutables los argumentos citados (págs. XXXI-XXXVI) en apoyo de este enfoque conservador y que desaconsejan, por ejemplo, incorporar al texto crítico del Libro de los fueros de Castilla lecciones provenientes del Fuero Viejo de Castilla de 1353, como hace Alvarado Planas en su edición de 2004. Emplear las lecturas que de las mismas disposiciones legales ofrecen otras tradiciones corre el riesgo de terminar presentando un texto "híbrido", de cuestionable valor filológico e histórico, ciertamente más coherente en lo que se refiere a la norma concreta pero totalmente ajeno al estadio sincrónico objeto de la edición (esto es, el arquetipo denominado Libro de los fueros de Castilla). Por lo demás, el cotejo de varias calas del 
texto crítico con el del manuscrito que se puede consultar en la reproducción digital de la Biblioteca nacional, confirma el rigor de la transcripción y la consistencia con la que se han aplicado los criterios editoriales expuestos en la introducción. En muy contadas ocasiones, sin embargo, encuentro erróneas, o al menos discutibles, algunas de las soluciones propuestas en cuanto a la separación de palabras y la puntuación del texto (véase, por ejemplo, págs. 248, 251, 258, 265 y 266). La edición va acompañada de un apéndice que una sección de notas sobre los rasgos dialectales apreciables en la lengua del códice, un excelente glosario de términos jurídicos de gran utilidad para el lector no especializado, así como sendos índices de topónimos y de nombres propios. La edición constituye, en suma, una importante aportación al medievalismo hispano, de referencia obligada para historiadores, filólogos y, en general, investigadores del derecho, la historiografía y la literatura, entre otros campos de estudio. Cabría además destacar el enorme interés que tienen los textos, especialmente algunas de las fazañas, desde el punto de vista literario pero, sobre todo, sociológico, como testimonio de actitudes, mentalidades y prácticas vigentes en la sociedad medieval y su valor, por tanto, como fuente primara para enfoques de investigación centrados, por ejemplo, en los estudios de género o las diversas perspectivas postcoloniales. 